\title{
Preliminary mineralogical study of the magnesian skarn from Valea Rea (Budureasa, Bihor Mountain, Romania)
}

\author{
ADRIAN IULIAN PANTIA, STEFAN MARINCEA, ANDRA \\ ELENA FILIUTA, DELIA-GEORGETA DUMITRAS AND \\ CRISTINA SAVA GHINET
}

Geological Institute of Romania

Presenting Author: padrian.iulian2020@gmail.com

The Valea Rea skarn occurrence is located in the Bihor Massif of the Apuseni Mountains, Romania, at the contact between the Budureasa laccolith (Upper Cretaceous) and the dolomitic limestone of the Ferice Nappe. The investigated samples were collected from the mine dump of the number 2 exploration shaft (N 46³9'49" - E 22³6'44"). The mineral association is made up of chrysotile and forsterite in mesh texture, phlogopite, and calcite veins, likely a remobilization product of the primary calcite resulting from the breakdown of dolostone protolith which host fluorapatite and, to a lesser extent, fluorite.

The present study was concerned with the chrysotile phlogopite - forsterite association, which was investigated using X-ray powder diffraction, electron microprobe analysis, micro Raman, and Fourier Transform Infrared Spectroscopy. EMPA results show the following mean values (wt \%): chrysotile (4 samples): $\mathrm{SiO}_{2}-40.38, \mathrm{TiO}_{2}-0.03, \mathrm{Al}_{2} \mathrm{O}_{3}-0.04, \mathrm{MgO}-40.81$, $\mathrm{FeO}_{\text {(total) }}-1, \mathrm{MnO}-0.1, \mathrm{CaO}-0.04, \mathrm{NiO}-0.03, \mathrm{Na}_{2} \mathrm{O}-0.01$, $\mathrm{K}_{2} \mathrm{O}-0.03$; phlogopite (10 samples): $\mathrm{SiO}_{2}-40.66, \mathrm{TiO}_{2}-0.65$, $\mathrm{Al}_{2} \mathrm{O}_{2}-15.17, \mathrm{FeO}_{\text {(total) }}-1.3, \mathrm{MnO}-0.03, \mathrm{MgO}-25.83, \mathrm{CaO}-$ $0.04, \mathrm{Na}_{2} \mathrm{O}-0.02, \mathrm{~K}_{2} \mathrm{O}-10.66, \mathrm{H}_{2} \mathrm{O}-3.59, \mathrm{~F}-1.48, \mathrm{O}=\mathrm{F}-$ -0.63 ; forsterite (7 samples): $\mathrm{SiO}_{2}-42.3, \mathrm{TiO}_{2}-0.01, \mathrm{Al}_{2} \mathrm{O}_{2}-$ $0.01, \mathrm{MgO}-55.16, \mathrm{FeO}_{\text {(total) }}-2.01, \mathrm{MnO}-0.1, \mathrm{CaO}-0.08$, $\mathrm{NiO}-0.06, \mathrm{Na}_{2} \mathrm{O}-0.01, \mathrm{~K}_{2} \mathrm{O}-0.02$. The lattice parameters of representative samples, calculated by the least squares method, are as follows: chrysotile: $\mathrm{a}=5.312(7) \AA, \mathrm{b}=9.207(3) \AA, \mathrm{c}=$ 14.635(6) $\AA, \beta=93.66^{\circ}$; phlogopite: $\mathrm{a}=5.322(1) \AA, \mathrm{b}=$ 9.221(5) $\AA, c=10.251(7) \AA, \beta=100.023^{\circ}$; forsterite: $a=$ 7.758(6) $\AA, b=10.228(3) \AA, c=5.977(4) \AA$. The results of the micro Raman and FTIR measurements are consistent with those obtained using XRD and EMPA, showing the characteristic vibrational modes of the minerals discussed. 